\title{
HUMAN FLOW: ATRAVESSAR, CUSTE O QUE CUSTAR
}

\author{
Human Flow: pass through whatever it takes \\ Human Flow: atravesar, cueste lo que cueste
}

Ricardo Lessa Filho

Doutor pelo Programa de Pós-Graduação em Comunicação da Universidade Federal de Pernambuco (UFPE). ricardolessafilho@hotmail.com

Frederico Vieira Doutor pelo Programa Pós-Graduação em Comunicação da Universidade Federal de Minas Gerais (UFMG) Professor do Curso de Graduação em Relações Públicas (PUC-MG) frederico.vieira.souza@gmail.com

\section{Resumo}

Partindo do ensaio pouco conhecido de Hannah Arendt sobre os refugiados e das lapidações teóricas de Giorgio Agamben sobre o tema, como também da exposição sobre a hospitalidade de Jacques Derrida, o artigo propor-se-á a partir de Human Flow (2017), filme dirigido pelo artista e ativista chinês Ai Weiwei, exercer um olhar histórico, teórico e morfológico sobre as imagens registradas em diversos campos de refugiados, imagens que acabam por expelir ao nosso campo visual uma inconteste violência contra tantas vidas humanas, cujas "autoridades" dos países receptores destes imensos fluxos de pessoas deixam transparecer, ao mesmo tempo pela crueldade e indiferença, a enfermização de nossa condição humana e o aniquilamento de toda a ideia de hospitalidade - ali mesmo onde a genealogia da Europa e do mundo é renegada de maneira absoluta quando se passa a perceber o refugiado não mais como um estrangeiro, senão como um inimigo, como um ser hostil.

Palavras-chave: Human flow. Refugiados. Hospitalidade.

\begin{abstract}
Starting from the little-known essay by Hannah Arendt on refugees and the theoretical improvements by Giorgio Agamben on the subject, as well as the exposition on the hospitality by Jacques Derrida, the article will propose from Human Flow (2017), film directed by Chinese artist and activist Ai Weiwei, exercise a historical, theoretical and morphological point of view on the images recorded in various refugee camps, images that end up expelling to our visual field an uncontested violence against so many human lives and whose "authorities" of the host countries of these immense flows of people reveals, at the same time, by the cruelty and indifference, the infirmity of our human condition and the annihilation of the whole idea of hospitality - there where the genealogy of Europe and of the world is absolutely denied when it comes to perceiving the refugee no longer as a Foreigner, but as an enemy, as a hostile being.
\end{abstract}

Keywords: Human flow. Refugees. Hospitality. 


\section{Resumen}

A partir del ensayo poco conocido de Hannah Arendt sobre los refugiados y las lapidaciones teóricas de Giorgio Agamben sobre el tema, así como de la exposición sobre la hospitalidad de Jacques Derrida, el artículo se propondrá a partir de Human Flow (2017), película dirigida por el artista y activista chino Ai Weiwei, ejercer una mirada histórica, teórica y morfológica sobre las imágenes registradas en diversos campos de refugiados, imágenes que acaban por exponer a nuestro campo visual una incontestable violencia contra tantas vidas humanas, cuyas "autoridades" de los países receptores de estos inmensos flujos de personas dejan traslucir, al mismo tiempo por la crueldad e indiferencia, la enfermización de nuestra condición humana y el aniquilamiento de toda la idea de hospitalidad - allí mismo donde la genealogía de Europa y del mundo es renegada de manera absoluta cuando se pasa a percibir al refugiado no más como un extranjero, sino como un enemigo, como un ser hostil. Palabras clave: Human flow. Refugiados. Hospitalidad.

Um espectro ronda a Europa (Ein Gespenst geht um in Europa)

- K. Marx e F. Engels

E este estar-com os espectros seria também, não somente, mas também, uma política da memória, da herança e das gerações

- J. Derrida

Quando nos aparece um espectro, é nossa própria genealogia que emerge à luz

- G. Didi-Huberman

\section{INTRODUÇÃO}

Em 1933 Hannah Arendt tinha escapado por pouco dos campos de concentração alemães, e sucessivamente refugiada na Tchecoslováquia, depois na Suíça e em Paris - antes de sua partida definitiva para os Estados Unidos -, não pôde escapar, sem dúvida, em maio de 1940, nem ao Velódromo de Inverno de Paris nem ao campo de concentração de Gurs ${ }^{1}$. Mas como refugiada bem informada, conseguiu justamente "atravessar os muros", escapar dos alambrados de arames farpados do campo concentracionário antes de conseguir cruzar a fronteira. Consequentemente estava bem localizada, tanto no plano prático como no plano histórico e filosófico, para lançar certa luz sobre a experiência do refugiado.

\footnotetext{
${ }^{1} \mathrm{O}$ Velódromo de Inverno de Paris foi o maior aprisionamento de massa de judeus realizado na França durante a Segunda Guerra Mundial. Entre o 16 e 17 de Julho de 1942, 13.152 pessoas das quais quase um terço eram crianças, foram presos em Paris e seus arredores; 8.160 foram detidos no Velódromo de Inverno de Paris durante quatro dias. Quase todos foram mortos, menos de cem sobreviveram a deportação. Já o campo de concentração de Gurs, criado como campo de refugiados espanhóis na França em 1939, por motivos da guerra civil espanhola, foi convertido a partir de 1940 em campo de concentração nazista.
} 
A partir desta experiência como refugiada, em 1943 Hannah Arendt (2013) escreveu para a revista The Menorah Journal, que era então o principal órgão da literatura e do pensamento judaico em língua inglesa, um ensaio chamado Nós, os refugiados (We refugees), no qual ela discutia, com um conhecimento de causa interminável, a questão daqueles novos apátridas (stateless) que a segunda guerra e o nazismo tinham expelido à Europa - isto é, ao continente maculado pelas guerras sucessivas já cessadas, pela grande guerra ainda em vigência, pelo racismo incontornável do nazi-fascismo e do colonialismo. O que é precioso, nas palavras de Arendt exatamente 75 anos depois, é o olhar que, já expelida de sua própria terra (a Alemanha), ela pôde exercer com tamanha humanidade - e não sem a dor e o sofrimento que tal situação exigia - uma radiografia sobre aquilo que, senão inédita em sua forma, nunca antes tão potente em sua insistência e quantidade, marcaria de maneira incessante as vidas dos refugiados e apátridas ao longo de todo o século $\mathrm{XX}$ e do recente século XXI: a perda, justamente, daquilo que Arendt tão tenazmente debruçou-se para nomear durante sua vida: a condição humana.

No referido texto, a filósofa alemã faz irromper logo em seu início a ferida causada por essa então inesperada condição humana - ali onde a violência política e estatal corrói todo o sentido não só de uma ética ou de uma dignidade humana, mas também do próprio ser refugiado, isto é, alguém que busca um refúgio (fugindo da guerra, da morte), um lar, uma possibilidade de continuar a viver fora de sua pátria malgrado tudo:

Um refugiado costuma ser uma pessoa obrigada a procurar refúgio devido a algum ato cometido ou por tomar alguma opinião política. Bom, é verdade que tivemos que procurar refúgio; mas não cometemos nenhum ato e a maioria de nós nunca sonhou em ter qualquer opinião política radical. O sentido do termo "refugiado" mudou conosco. Agora "refugiados" são aqueles de nós que chegaram à infelicidade de chegar a um novo país sem meios e tiveram que ser ajudados por comitês de refugiados (ARENDT, 2013, p. 7).

E em 1995 coube a Giorgio Agamben, em um ensaio intitulado Para além dos direitos do homem $(2001)^{2}$, resgatar o então pequeno e brilhante texto de Arendt àquela altura ainda jamais reimpresso ${ }^{3}$, e neste gesto de resgate restituir, justamente, ao seu próprio tempo - que é também o nosso - a corrosão geral das categorias jurídico-políticas tradicionais, assim como o

\footnotetext{
${ }^{2} \mathrm{O}$ título do texto de Agamben não é de nada estranho ao título do último subcapítulo ( $O$ declínio do Estadonação e o fim dos direitos do homem) que encerra, justamente, o capítulo sobre o imperialismo e que antecipa o início do capítulo sobre o totalitarismo em uma das obras mais importantes de Arendt (1989).

${ }^{3} \mathrm{O}$ texto We refugees foi republicado há pouco mais de uma década no livro Jewish Writings (2007), editado por Jerome Kohn e Ron H. Feldmann, que aglomera o conjunto de textos em torno do judaísmo escritos por Hannah Arendt.
} 
retorno incessante que os refugiados (como espectros que se revelam) realizam na Europa e no mundo - como se para clamarem uma dignidade, diríamos inclusive, um lugar legítimo no mundo:

Arendt inverte a condição de refugiado que perdeu todo direito e cessa, porém, de querer assimilar-se a qualquer custo a uma nova identidade nacional, para contemplar lucidamente sua condição, recebe, em troca de uma impopularidade segura, uma vantagem inestimável: "a história não é mais, para ele, um livro fechado, e a política deixa de ser o privilégio dos Gentis [...]". Convém refletir sobre o sentido dessa análise, que hoje, exatamente a cinquenta anos ( 75 anos) de distância, não perdeu em nada de sua atualidade. Não só o problema se apresenta na Europa e fora dela, com idêntica urgência, mas, no declínio agora irrefreável do Estado-nação e na corrosão geral das categorias jurídico-políticas tradicionais, o refugiado é, talvez, a única figura pensável do povo no nosso tempo e, ao menos até quando não for realizado o processo de dissolução do Estado-nação e da sua soberania, a única categoria na qual é hoje permitido entrever as formas e os limites de uma comunidade política por vir (AGAMBEN, 2001, p. 21-22).

Mas para falar de tais massas de seres humanos (desta "única figura pensável do povo no nosso tempo"), para compreender melhor com as ferramentas que dispomos a questão simplesmente incalculável dos refugiados tanto hoje como no início do século XX, é preciso registrar esta história de alguma maneira matemática. A primeira aparição dos refugiados como um fenômeno de massa ocorreu no fim da Primeira Guerra Mundial, em que o colapso dos impérios da Rússia, Austro-Hungria e Otomano, e a nova ordem criada pelos tratados de paz alteraram com grande profundidade as bases demográficas e territoriais do leste e do centro europeu. Em um curto período, um milhão e meio de russos brancos, 700 mil armênios, 500 mil búlgaros, um milhão de gregos, e centenas de milhares de alemães, húngaros e romenos deixaram seus países e moveram-se para outros lugares. Para aquelas massas em movimento deveria ser adicionada a situação explosiva determinada pelo fato de que os novos organismos estatais criaram através dos tratados de paz um modelo de estadonação que compreendia as minorias que tinham sido protegidas por uma série de tratados internacionais (os famosos Minority Treaties), que muito frequentemente permaneceu letra morta. Alguns anos depois, as leis raciais na Alemanha e a guerra civil na Espanha disseminaram uma nova e substancial quantidade de refugiados através da Europa (AGAMBEN, 2001, p. 22-23).

No nosso presente, as guerras civis e a pobreza extrema no Oriente Médio e no continente africano fizeram com que a intensidade da crise dos refugiados na Europa, com perdas de milhares de vidas no Mar Mediterrâneo, seja comparada aos eventos vividos no 
continente europeu durante e imediatamente após a Segunda Guerra Mundial, quando cerca de 60 milhões de pessoas tiveram de fugir de suas terras. A isto, elucida-se que de fato o movimento de refugiados e de pessoas em busca de proteção no continente europeu nunca desapareceu (RICHMOND, 1993), ao mesmo tempo que os refugiados, com maior ou menor intensidade, permanecem como uma dimensão inesgotável das migrações para a (e na) Europa nas últimas sete décadas (FIDDIAN-QASMIYEH, 2014), e não por acaso, estas sete décadas possuem a mesma "idade" do ensaio We refugees de Hannah Arendt.

E a partir deste caminho traçado por Arendt e retraçado por Agamben, diríamos inclusive desta (re)abertura para voltar a pensar tal questão, o artigo propor-se-á a partir de Human Flow (2017), filme dirigido pelo artista e ativista chinês Ai Weiwei ${ }^{4}$, exercer um olhar histórico, teórico e morfológico sobre as imagens registradas em diversos campos de refugiados na Europa, imagens que acabam por expelir ao nosso campo visual uma inconteste violência contra tantas vidas humanas, cujas "autoridades" dos países receptores destes imensos fluxos de pessoas deixam transparecer, ao mesmo tempo pela crueldade e indiferença, a enfermização de nossa condição humana e o aniquilamento de toda a ideia de hospitalidade - ali mesmo onde a genealogia da Europa e do mundo é renegada de maneira absoluta quando se passa a perceber o refugiado não mais como um estrangeiro, senão como um inimigo, como um ser hostil.

\section{HUMAN FLOW: ELES CHEGAM PELO MAR}

Human Flow é iniciado (FIG. 1) em um plano azul, incalculável por sua própria imensidão, de um mar e um quase imperceptível ponto branco - uma gaivota provavelmente que se move como para nos lembrar que os seres humanos, tais como as aves, são seres migratórios. Ai Weiwei parece inscrever assim, logo no primeiro plano de seu filme, a própria potência migratória das vidas humanas. O plano conseguinte (FIG. 2): o mesmo azulado, a mesma insistência pela distância da terra: um barco que parece levar algumas pessoas, alguns refugiados. O ponto branco agora foi multiplicado, o que por sua brancura emerge na tela é a reação espumática do mar ao motor da embarcação.

\footnotetext{
${ }^{4}$ Alguns dias antes de escrevermos estas linhas, o estúdio de Ai Weiwei em Beijing foi demolido sem aviso prévio das autoridades chinesas ao seu proprietário (BBC, 2018).
} 


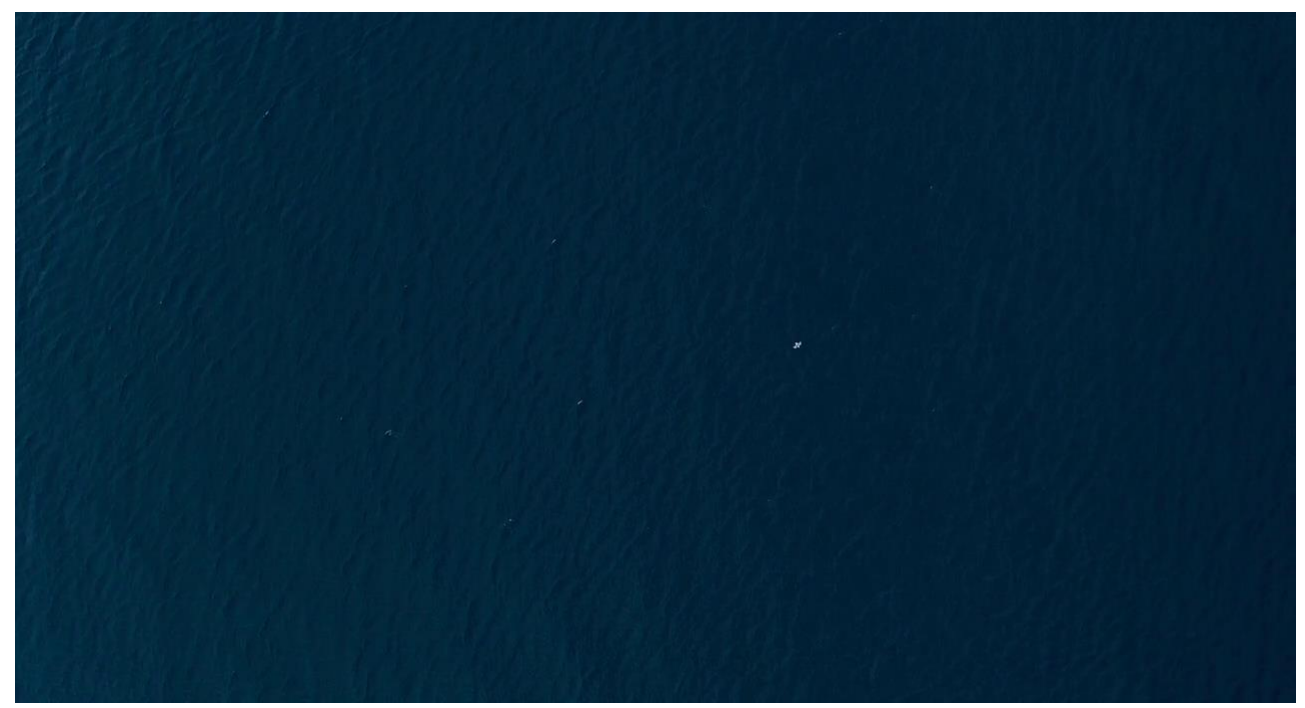

Figura 1 - O ponto branco de uma gaivota que atravessa o mar mediterrâneo

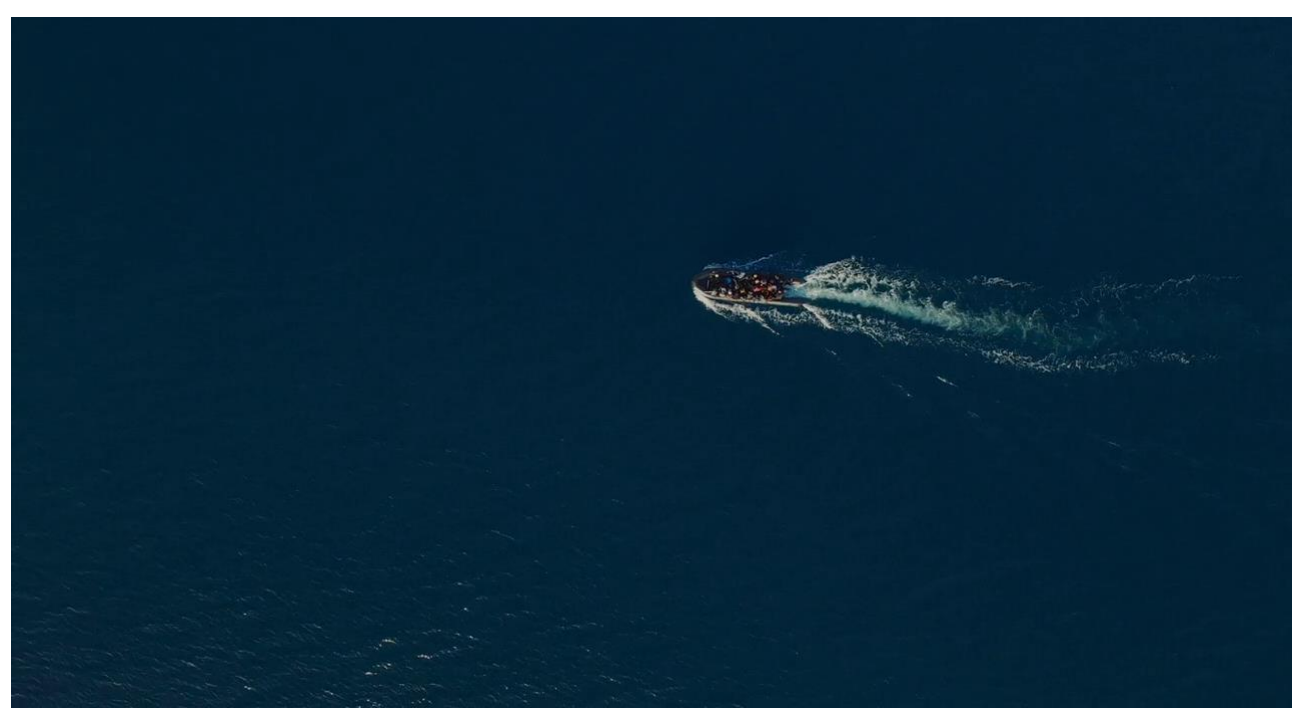

Figura 2 - Os pontos brancos agora surgidos no mar por causa do motor da embarcação

Quando a câmera-drone de Ai Weiwei “desce” (FIG. 3), finalmente vemos algumas cores para além do azul oceânico ou do branco espumático: os laranjas dos coletes salvavidas, mas mais do que isso: os corpos pressionados de duas dezenas de refugiados em um bote. Sim, agora o filme parece registrar uma ideia de terra, de chão mesmo ainda no mar - e este é o único gesto, a única altura possível que pode oferecer aos refugiados uma dignidade às suas vidas colocadas, a partir de agora, sob tais condições de apatridia. E sobre estas condições tantas vezes distintas, a de ser um refugiado e ser um apátrida, Giorgio Agamben (2001, p. 22) escreve que em nosso tempo essa outrora separação já é quase sempre indissociável, porque o refugiado como aquele que foge de sua própria terra (para escapar das 
guerras civis, da morte) para um outro país já não pode ter, justamente, uma cidadania, isto é, um reconhecimento político-jurídico de sua identidade e desta maneira acaba por submergir no status de apátrida.

É impossível não pensarmos dolorosamente, com Agamben e à luz dos refugiados, sobre a ideia mesma do homo sacer, este ser para sempre excluído da esfera jurídica e política, cujo assassinato estará de maneira interminável na suspensão da lei - na sua incapacidade, portanto, de oferecer uma dignidade à esta vida (nua) e uma justiça a este crime (AGAMBEN, 2002). Das dezenas de milhares de vidas perdidas no Mar Mediterrâneo nos últimos anos, desta ruptura jurídico-política que irrompe toda vez que a questão dos refugiados é posta em discussão, a barbárie do mundo nos assalta para nos lembrar, com sua força cruel, da precariedade da vida de tantos seres humanos.

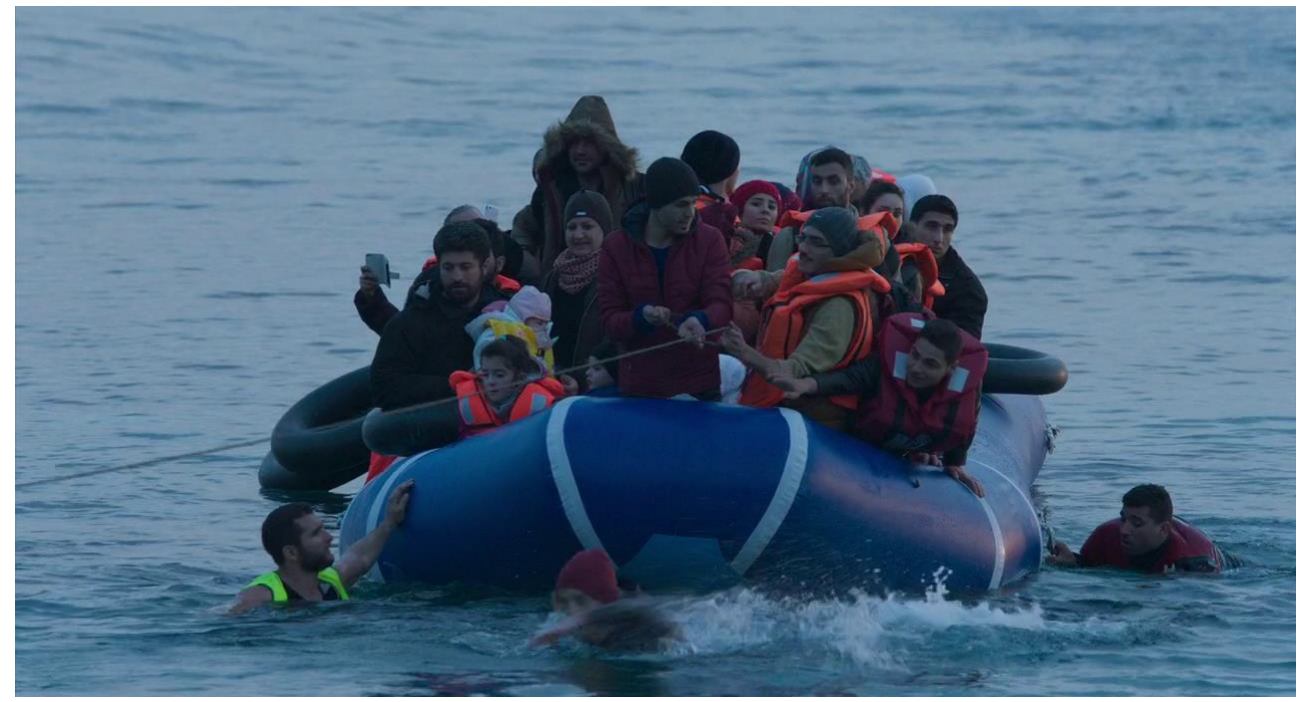

Figura 3 - A embarcação, que com duas dezenas de refugiados imprensados, aproxima-se da terra firme

\subsection{Os espectros que rondam a Europa}

Em seu texto de 1943, Hannah Arendt numa passagem elucidativa metaforiza a questão histórica dos refugiados - e sua sistemática abnegação por parte do mundo civilizado e ocidental em acolhê-los - como que se o mundo europeu os tendo expelidos da maneira como os expeliu à apatridia e negando-lhes consequentemente uma identidade e dignidade, negasse-lhes também uma própria memória histórica, ali mesmo onde as histórias de fantasmas já não mais completariam sua função mesma de arrepiar e assombrar as pessoas, ali mesmo onde diante desta então nova e aterradora realidade era preciso de uma experiência real, de uma carne que sangrasse (ou se afogasse) de verdade: 
Pensamos que as estrelas são mais conselheiras, mais confiáveis do que todos os nossos amigos; aprendemos das estrelas quando devemos almoçar com os nossos benfeitores e em que dia temos mais hipóteses de preencher um desses incontáveis questionários que acompanham as nossas vidas presentes. Por vezes não confiámos nem nas estrelas mas, antes, nas linhas das nossas mãos ou na grafologia. Assim aprendemos menos sobre os acontecimentos políticos mas mais sobre os nossos queridos seres [...]. Não querem mais histórias de fantasmas; é a experiência real que faz arrepios na sua carne. Não há mais necessidade de enfeitiçar o passado; já há feitiço suficiente na realidade. Assim, em vez do nosso falado otimismo, usamos todos os tipos de truques mágicos para evocar os espíritos do futuro (ARENDT, 2013, p. 9; grifo nosso).

Em Espectros de Marx (1994), Jacques Derrida define com a tenacidade formal que lhe é tão cara, uma certa história de fantasmas, de espectros, estes seres que revelam-se sempre tão próximos a nós - seja pela já ausência, pela morte, seja pelo nascimento ainda não completado - como se para reclamar uma presença alastrada, pungida, ferida, ali onde os espectros tornam-se por sua genealogia questões de nossa própria herança:

Se me apresto a falar longamente de fantasmas (espectros), de herança e de gerações, de gerações de fantasmas, ou seja, de certos outros que não estão presentes, nem presentemente vivos, nem para nós, nem em nós, nem fora de nós, é em nome da justiça. Da justiça onde ela ainda não está presente; aí onde ela não está mais, entenda-se, aí onde ela não está mais presente, e aí onde ela nunca será, não mais do que lei, redutível ao direito. É preciso falar do fantasma, até mesmo ao fantasma e com ele, uma vez que nenhuma ética, nenhuma política, revolucionária ou não, parece possível, pensável e justa, sem reconhecer em seu princípio o respeito por esses outros que não estão mais ou por esses outros que ainda não estão aí, presentemente vivos, quer já estejam mortos, quer ainda não tenham nascido. Justiça alguma - não digamos lei alguma, e mais uma vez lembro que não falamos aqui do direito - parece possível ou pensável sem o princípio de alguma responsabilidade, para além de todo presente vivo, nisto que desajunta o presente vivo, diante dos fantasmas (espectros) daqueles que já estão mortos ou ainda não nasceram, vítimas ou não das guerras, das violências, políticas ou outras, dos extermínios nacionalistas, racistas, colonialistas, existas ou outros, das opressões do imperialismo capitalista ou de todas as formas do totalitarismo. Sem essa não-contemporaneidade a si do presente vivo, sem isto que secretamente o desajusta, sem essa responsabilidade e respeito pela justiça com relação a esses que não estão presentes, que não estão mais ou ainda não estão presentes $e$ vivos, que sentido teria formular-se a pergunta “onde?", “onde amanhã?" (DERRIDA, 1994, p. 11-12).

E não é na fissura mesma de nossa história onde o espectro emerge, ou melhor, rondanos? Mas o espectro como uma evocação obsedante também não expele ao mesmo tempo alguma coisa do passado e alguma coisa da esperança - do “onde”, do “onde amanhã”? E quando as imagens dos refugiados irrompem em Human Flow parece reclamar-nos a olhar 
suas condições degradantes, a maneira impiedosa em que, independentemente da idade, estas vidas humanas são tratadas. Numa imagem (FIG. 4) logo após mais uma embarcação chegar à terra firme, vemos os refugiados na ilha grega de Lesbos sendo conduzidos a uma espécie de tenda e aglomerados dentro deste local escuro onde apenas um lampião parece tentar iluminar todo aquele espaço. Os espectros então, como aqueles de outrora, como aqueles que ainda virão reclamar sua história, emergem nesta imagem: os refugiados entendidos como seres de exceção, como colônias de inimigos, lançados impiedosamente no coração da escuridão justamente eles que acabaram de atravessar o mar escuro da morte, justamente eles que suplicam somente um abrigo, um lar, um trabalho, qualquer coisa sem dúvida que os ajudem a recuperar uma ideia de dignidade.

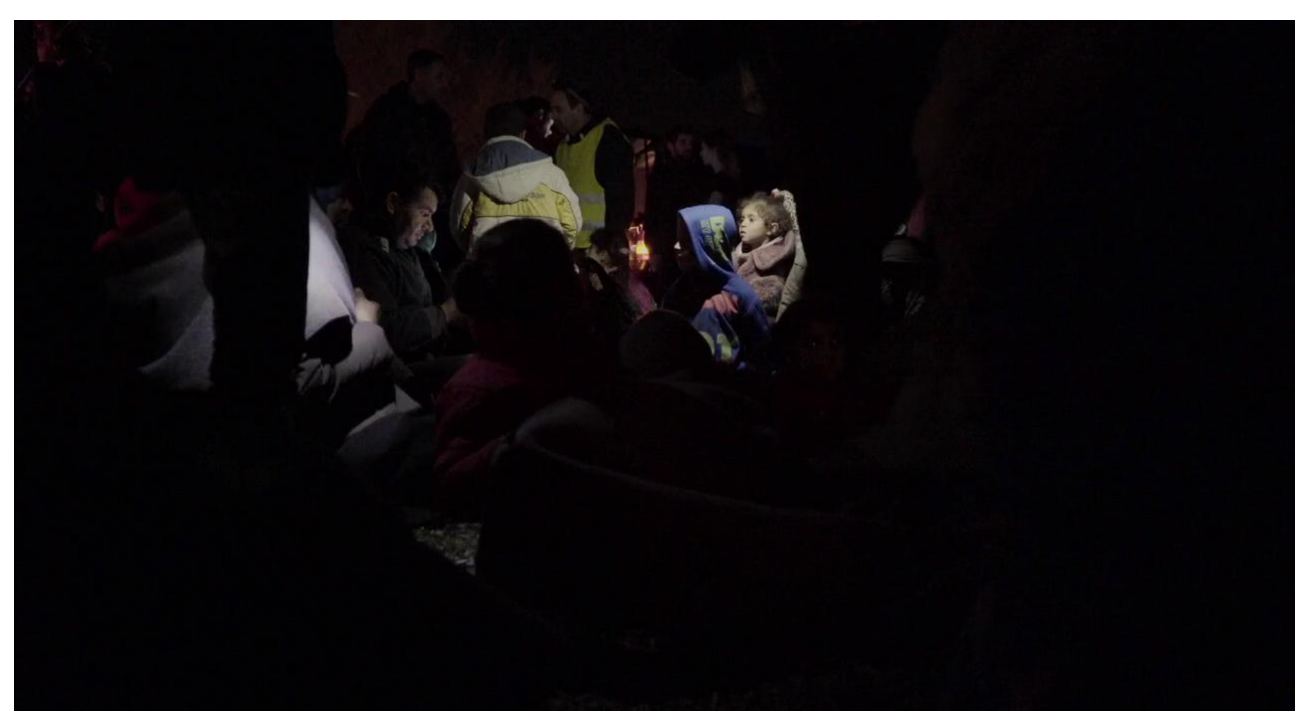

Figura 4 - Os refugiados, já em terra firme, lançados na escuridão e entendidos como seres de exceção

Cabeças encapuzadas ou corpos dissimulados sob grandes vincos monocromáticos ou coloridos, em todos os casos os refugiados parecem espectros, esses seres de outra parte que a boa consciência teme, deseja conjurar, quisera ignorar ou saber duas vezes mortos no lugar de uma, mas diante dos quais nossos olhos não podem fazer outra coisa - das nem tão distantes fronteiras da Europa até as esquinas das ruas - senão constatar sua passagem perpétua, seu obstinado retorno.

É por isso que os refugiados atravessam custe o que custar. Como espectros que perpassam uma parede de concreto, como um fantasma que se materializa diante de nossos olhos sua aparência inesperada. Os seres humanos, sejam espectrais ou carnais, são seres que migram de um lugar a outro, são organismos vivos que vão e voltam, que são capazes a partir 
da tenacidade inquebrantável do desejo de viver em atravessar já seja um arame farpado, um muro ou um oceano. Mas por_que então os refugiados, seja na época de Arendt ou em nosso presente, são insistentemente percebidos como inimigos, como seres abjetos quando na verdade o que eles desejam é uma nova chance para viver suas vidas sempre tão próximas de serem mutiladas pelas guerras civis, pela pobreza extrema, pela morte?

\section{OS NOSSOS PAIS QUE VOLTAM OU DA HOSPITALIDADE QUE NÃO PODEMOS NEGAR}

Em um recente opúsculo Georges Didi-Huberman, debruçando-se sobre as imagens dos refugiados da aldeia grega de Idomeni (região fronteiriça com a Macedônia) e com a clareza e beleza que obstinadamente atravessam sua obra, propõe que os refugiados não realizam outra coisa senão regressar, e no momento mesmo em que negamos esse regresso, buscamos conjurar algo que já existiu, algo inserido em nossa própria genealogia. Nesta conjuração - portanto, neste distanciamento do "medo" e do "mal" - acaba-se por não perceber que, em maior ou menor medida, todos nós somos filhos de migrantes - ali mesmo onde todo ser humano é capaz de exercer sua potência migratória que lhe define -, e negarlhes o regresso é como negar os nossos pais que voltam apesar que na maioria das vezes (por pura ignorância ou por perversidade) renunciamos esta inesperada familiaridade:

Depois de tudo, os refugiados não fazem senão regressar. Não "desembarcam" do nada nem de nenhuma parte. Quando consideramos hordas de invasores vindos de terras hostis, quando confundimos neles o estrangeiro com o inimigo, isso quer dizer, sobretudo, que tentamos conjurar algo que, de fato, já existiu: algo que reprimimos de nossa própria genealogia. Esse algo é que todos somos filhos de migrantes e que os migrantes não são senão nossos pais que voltam, ainda que sejam "distantes" (como às vezes dizemos dos primos) (DIDI-HUBERMAN, 2018, p. 31).

É preciso então repetir as palavras de Didi-Huberman, prestar-lhes a atenção devida: "nossos pais que voltam" (nos parents qui reviennent). Ninguém pode retornar a um lugar em que nunca esteve, porque somente alguém que o habitou pode retornar a ele. É nesta simples e bela definição ("nossos pais que voltam") que podemos inferir a condição dos refugiados como seres inermes e prescindidos de toda e qualquer restituição tanto histórica quanto cartográfica, porque o fato muito evidente de que antes de nós existiram os migrantes que habitaram o lugar onde hoje moramos, seja no continente americano ou europeu, africano, oceânico ou asiático, porque a autoctonia que aponta, hoje em dia, o emprego paranoico da 
palavra "identidade" simplesmente não existe, e é porque toda região, toda cidade ou toda aldeia estão habitadas por povos (em sua pluralidade), povos que coexistem, que coabitam, e jamais por "um povo" autoproclamado em sua fantasia de "pura ascendência" - como acreditavam os nazistas, como acreditam os novos fascistas.

E talvez uma possibilidade para pensar acerca de uma restituição histórica aos refugiados seria, justamente, debruçarmo-nos sobre o exercício de nossa responsabilidade, do retorno fundamental de nossa hospitalidade para com esta espécie de familiar distante que insistimos em desconhecer, em ignorar - porque estes seres vindos de outra parte jamais deveriam ser estranhos no reconhecimento de nossa própria genealogia. Jacques Derrida em Espectros de Marx (1994) pensou de modo muito lúcido a partir de questões éticas e políticas induzidas tanto pelo estado de apartheid (o livro foi publicado originalmente em 1993, portanto, na reta final da questão racial da África do Sul) como por todas as conjurações incluídas as "declarações de morte" - brandidas do medo obsessivo ao estrangeiro e da ignorância do significado de hospitalidade: a saber, o temor de que o "espectro", aquele que regressa de outro lugar ou de outro tempo, transforme-se em nosso concidadão e, pior ainda, em nosso igual, em nosso semelhante.

Em outros debruçamentos sobre o tema, Derrida $(1999,2003)$ refere-se a dois tipos de hospitalidade: a hospitalidade condicional como aquela que é ofertada pelo direito, pela política, pela antropologia etc; E a uma hospitalidade incondicional, que é narrada pelo conto exemplar do Desvalido no Caminho. Esta hospitalidade não é outra coisa senão a exposição à vinda daquele que vem, portanto, de seu acolhimento mais verdadeiro. Será uma hospitalidade que dá aquilo que não possui, aquilo que não dispõe como próprio. Assim, é uma hospitalidade como impossibilidade. Faz o impossível e é, não apenas impossível, senão um convite a fazer por si mesmo aquilo que já é impossível. Logo, a hospitalidade absoluta exige que nos abramos em nosso próprio lar - em nossos territórios, em nossas fronteiras mais profundas - e que nos ofereçamos não só ao estrangeiro, como também ao Outro absoluto (Autre absolu), desconhecido, anônimo, e que ao nos darmos de tal maneira, que o deixemos vir, que o deixemos chegar e ter um lugar no lugar, que lhe ofereçamos, sem lhe exigir reciprocidade, nem mesmo o seu nome. A hospitalidade incondicional, mais do que despertar alguém oferecendo flores, é acolhê-lo em nosso próprio mundo.

Derrida (2003) assim torna visível que a hospitalidade não pode existir incondicionalmente, que ela é ao mesmo tempo indecidível e/ou impossível e que no exercício de toda hospitalidade há uma soberania que viola aquele que entra em meu território 
ou ainda, que me viola por deixar que o Outro entre em mim. E este outro é, justamente, o estrangeiro - que é visto hoje, na figura do refugiado, como horda inimiga -, aquele que vem ou virá (mas sempre chegará depois de nós, os "autóctones"), e do qual precisará da hospitalidade para reconhecer-se como parte de um novo mundo que ele busca habitar. E é nesta incapacidade de reconhecer o estrangeiro como semelhante que a "crise dos refugiados" alastrou-se de tal maneira, propagou-se a partir da ruptura de um pacto em defesa ao estrangeiro, do estilhaçamento da hospitalidade em relação ao Outro, da nossa incapacidade, sem dúvida, em reconhecer a nossa própria genealogia esquecida:

Trata-se de saber se esse pacto, esse contrato de hospitalidade que liga ao estrangeiro e que liga reciprocamente o estrangeiro, vale para além do indivíduo e se estende-se, assim, a toda a família, à geração, à genealogia. Não se trata, ainda que as coisas sejam conexas, do problema clássico do direito à nacionalidade ou à cidadania como direito de nascença-ligado, aqui, ao solo e, lá, ao sangue. Não se trata apenas do elo entre nascimento e nacionalidade; não se trata apenas da cidadania oferecida a alguém que não a tinha anteriormente, mas do direito acordado ao estrangeiro enquanto tal, ao estrangeiro que continua estrangeiro, e aos seus, à sua família, a seus descendentes (DERRIDA, 2003, p. 21).

De uma imagem possível desta hospitalidade negada ao refugiado, Human Flow nos mostra muito tenazmente em um momento (FIG. 5) o vazamento ao mesmo tempo da estaticidade e da locomoção, quando em um plano à altura do chão que registra quase à contraluz (essa forma tão singular de fazer voltar à escuridão as coisas iluminadas) dois pequenos seres ali mesmo abandonados em suas respectivas inermidades: uma garotinha de costas, estática, apoiando sua mão esquerda por sobre a corda da barraca onde se encontra, e à sua frente, um jovem iraquiano, um pouco mais velho, a movimentar-se - e que, sem saber, oferece a este momento de estaticidade uma possibilidade de locomoção, de migração apesar de tudo. Todavia nesta imagem há de fato uma conjuração, um isolamento do mundo destas duas pequenas vidas expostas a tal realidade. 




Figura 5 - Duas crianças iraquianas em um campo de refugiados

Destas crianças, destas inocências tão verdadeiras é preciso que lembremos de nossa idade, de nossa condição adulta, na qual basta uma acumulação de vida, ainda que seja neutra e cinza, para que nossas esperanças mais firmes e nossos desejos mais intensos se desmoronem. Desta vulnerabilidade em que estão expostas diante dos olhos do mundo a vida de tantos seres humanos não é ainda mais covarde, brutal e imperdoável a condição que o "mundo europeu" impõe a estas pequenas vidas? Mas nesta imagem (FIG. 5), insistindo pelo véu da esperança, não reside alguma coisa de passagem, de atravessamento? Na geometria impecável do plano de Ai Weiwei o garoto que habita-o não parece por sua motricidade incitar-nos à ideia mesma de migração, justamente, de um gesto migratório - ali onde somente por sua força motriz e por seu desejo de viver ele poderá atravessar as fronteiras e os muros do campo de refugiados onde se encontra -, desta herança (a do poder migratório) que é intrínseca a todos nós, refugiados ou não?

De um refugiado de Myanmar (FIG. 6) que fala sobre sua ponte de safena recém colocada, que fala da hérnia de disco de sua mulher e de toda exaustão - de toda exigência para atravessar e alcançar o campo de refugiados onde agora se encontra. Nesta imagem, em seu plano de fundo, as roupas estendidas sem ordem, as barracas ocupadas de qualquer maneira, mas sobretudo o que aos nossos olhos emergiu foi a dupla potência como imagem dos sapatos no lado direito deste enquadramento. Ao mesmo tempo porque nos remeteu às palavras de Martin Heidegger (2005) a partir dos quadros das botas dos camponeses que diversas vezes Vincent Van Gogh (FIG. 7) pintara e também pela imagem mesma da natureza deste apetrecho: a saber, a representação da marcha, da migração humana, da força 
(locomotora, braçal, motriz) dos seres apesar de tudo - desta "silenciosa alegria de vencer uma vez mais a miséria”. Por estas palavras, Heidegger deixou de ser, no exato instante em que as escrevia, um filósofo da ontologia do ser para tornar-se (por um breve momento) um filósofo da morfologia da imagem:

$\mathrm{Na}$ escura abertura do interior dos sapatos, fita-nos a dificuldade e o cansaço dos passos do trabalhador. Na gravidade rude e sólida dos sapatos está retida a tenacidade do lento caminhar pelos sulcos que se sentem até longe, sempre iguais, pelo campo, sobre o qual sopra um vento agreste. No couro, está a fertilidade e humidade do solo. Sob as solas, insinua-se a solidão do caminho do campo, pela noite que cai. No apetrecho para calçar impera o apelo calado da terra, a sua muda oferta de trigo amadurece e a sua inexplicável recusa na desolada improdutividade do campo no inverno. Por este apetrecho passa o calado temor pela segurança do pão, a silenciosa alegria de vencer uma vez mais a miséria, a angústia do nascimento iminente e o tremor ante a ameaça da morte. Este apetrecho pertence à terra e está abrigado no mundo da camponesa. É a partir desta abrigada pertença que o produto surge para o seu repousar-em-si-mesmo (HEIDEGGER, 2005, p. 25-26).

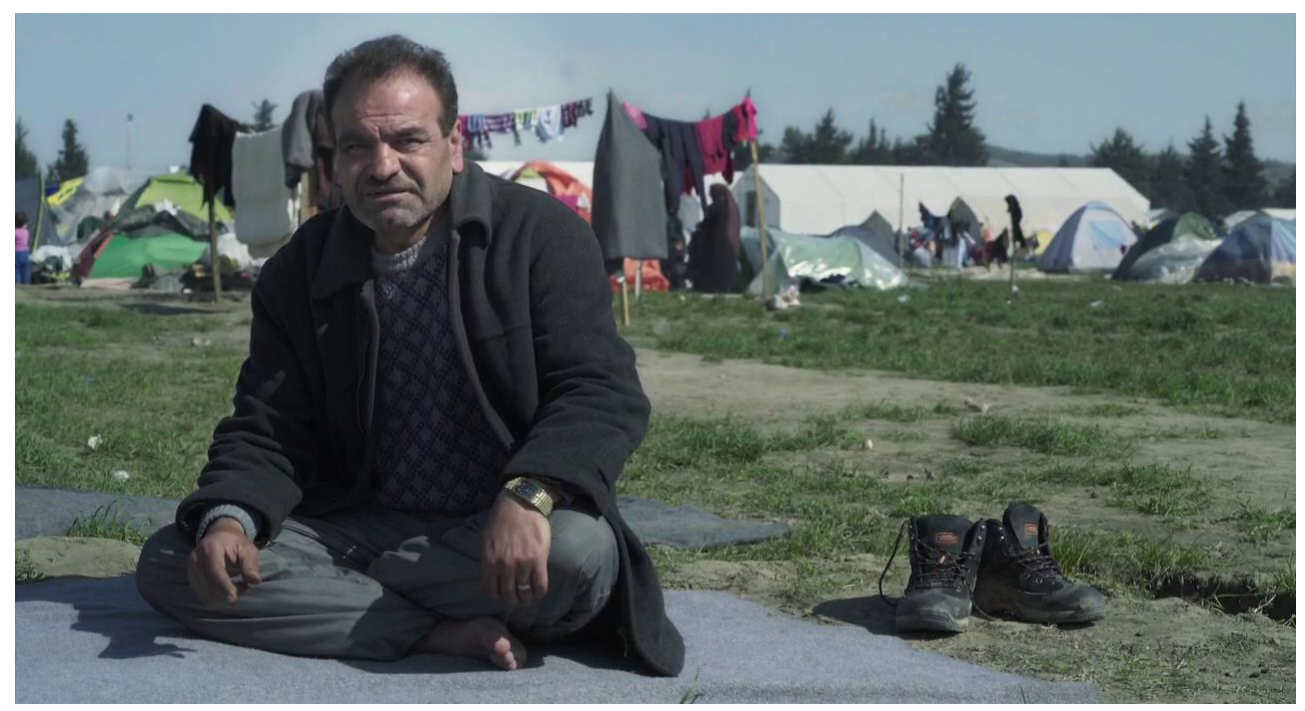

Figura 6 - Um refugiado de Myanmar e seus sapatos 


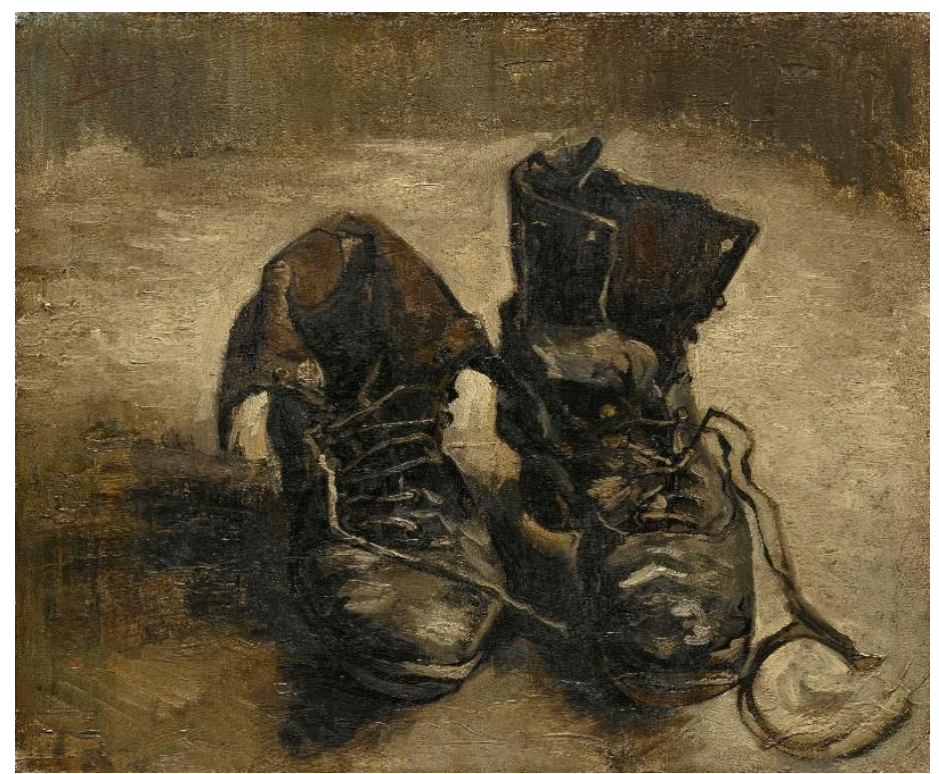

Figura 7 - Sapatos (1886), de Vincent Van Gogh

\subsection{Da herança, do estrangeiro e do atavismo}

É então que o ponto comum a todo refugiado vai em Human Flow emergir, isto é, o momento exato que eles terão de atravessar, custe o que custar, a geografia, a geologia das fronteiras. E se eles desesperadamente buscam atravessar as anfractuosidades dos territórios é para fazer sobreviver algo de sua herança, de seu tesouro mais profundo. A esta ideia de herança, de tesouro ${ }_{2}$ escreve Jacques Derrida:

Somos herdeiros, o que não quer dizer que ou que recebemos isto ou aquilo, que tal herança nos enriquece um dia com isto ou aquilo, mas que o ser disso que somos, primeiramente, herança, o queiramos, saibamos ou não. E sobre o quê, Hördelin o diz tão bem, só podemos testemunhar. Testemunhar seria testemunhar do que somos à medida que herdamos, e aí está o círculo, aí está a oportunidade ou a finitude, herdamos isto mesmo que nos permite dar testemunho. Hördelin chama a isso de linguagem, "o mais perigoso dos bens", dado ao homem, "a fim de que ele testemunhe ter herdado / isto que ele é (damit er zeuge, was er sei / geerbt zu haben)" (DERRIDA, 1994, p. 79).

Desta herança respondida por Derrida ("somos herdeiros", "recebemos isto ou aquilo", "somos à medida que herdamos"), parece convergir, justamente, algo do estrangeiro que habita todas as fronteiras do mundo. Mas o estrangeiro na figura do refugiado (é preciso insistir nisso), tanto na época de Arendt como hoje em dia, não pode receber nenhuma palavra de boas-vindas (nenhuma hospitalidade) e não pode ser acolhido ou assimilado em parte alguma (ARENDT, 1989, p. 300). Talvez seja por isso que Giorgio Agamben, na esteira da 
filósofa alemã, tenha pensado justamente na ruptura, no elemento inquietante que o refugiado representa para as nossas categorias jurídico-políticas (que não deixam de ser, à sua própria luz, heranças daqueles que existiram antes de nós) dos Estados e de seus territórios: "se o refugiado representa, no ordenamento do Estado-nação, um elemento tão inquietante, é antes de tudo porque, rompendo a identidade entre homem e cidadão, entre natividade e nacionalidade, põe em crise a ficção originária da soberania" (AGAMBEN, 2001, p. 26).

"Quando nos aparece um espectro, é nossa própria genealogia que emerge à luz" (DIDI-HUBERMAN, 2018, p. 31). Um espectro seria então nosso "estrangeiro familiar". Sua aparição é sempre reaparição. É, portanto, um ser ancestral: um pai - distante, certamente que diversas vezes temos de ver regressar para casa, porque, se regressa, é provavelmente para reabrir entre nós uma secreta e persistente ferida relativa ao mesmo tempo à questão genealógica e atávica. O atavismo, sua etimologia, carrega em sua fundação a palavra latina atavus - ao mesmo tempo antepassado, ancestral, tataravô - e hoje é uma definição utilizada, justamente, quando se torna perceptível o retorno de heranças de características físicas ou psíquicas de nossos antepassados. Negar um solo de direito aos refugiados não seria simplesmente negar a nossa genealogia (nossos laços familiares mais profundos e esquecidos) e nosso atavismo (a cor de nossos olhos, a textura de nossos cabelos, os sulcos de nossos rostos)?

Foi Georg Simmel que escrevera, em 1908, algumas das mais belas páginas a dar conta da questão do estrangeiro - este familiar distante que retorna -, justamente em um ensaio intitulado Der Ausländer (O estrangeiro), no qual o grande sociólogo alemão percebe a figura do estrangeiro como um ser movente - isto é, migratório -, como também insiste na "firmeza transfronteiriça" que lhe concerne, para firmar que, de fato, o estrangeiro é um "elemento do grupo“ e a sua suposta diferença não é só inaparente senão inexistente - como para clamar com suas próprias palavras e estilo que negar ao estrangeiro um lugar no mundo é negar a nossa própria história lapidada como seres migratórios:

Se o mover for o contraste conceitual do fixar-se, com a liberdade em relação a cada ponto dado do espaço, então, a forma sociológica do "estrangeiro" representa, não obstante, e até certo ponto, a unidade de ambas as disposições. Revela também, certamente, que as relações concernentes ao espaço são, por um lado, apenas, a condição e, por outro, o símbolo das relações entre os seres humanos. [...] Fixo dentro de um determinado raio espacial, onde sua firmeza transfronteiriça poderia ser considerada análoga ao espaço, a sua posição neste é determinada largamente pelo fato de não pertencer imediatamente a ele, e suas qualidades não podem originar-se e vir dele, nem nele adentrar-se. [...] $O$ estrangeiro, contudo, é também um 
elemento do grupo, não mais diferente que os outros e, ao mesmo tempo, distinto do que consideramos como o "inimigo interno". É um elemento do qual a posição imanente e de membro compreendem, ao mesmo tempo, um exterior e um contrário. (SIMMEL, 2005, p. 265-266, grifo nosso).

Em uma determinada duração de Human Flow surgem mães e pais empunhando seus bebês (seus tesouros) para atravessar o trecho violento do córrego de um rio - a iminência da morte, que parece perseguir insistentemente todo refugiado, irrompe aqui com uma sombra escandalosa. No mesmo momento aparecem refugiados tentando formar um cordão humano para assegurar a travessia de todos que estão no grupo e as fisionomias de pavor e angústia são evidentes. Alguns instantes, então, que Ai Weiwei registra sobre a condição terrível e lancinante destes seres: já não bastasse não ter uma terra (um lugar onde sua identidade, sua pátria poderia ser reconhecida e exercida; um lugar, portanto, onde sua herança poderia ser exposta, cuidada, proliferada), também ter de lidar com as ameaças naturais da própria topografia que eles tentam atravessar (FIGS. 8 e 9).

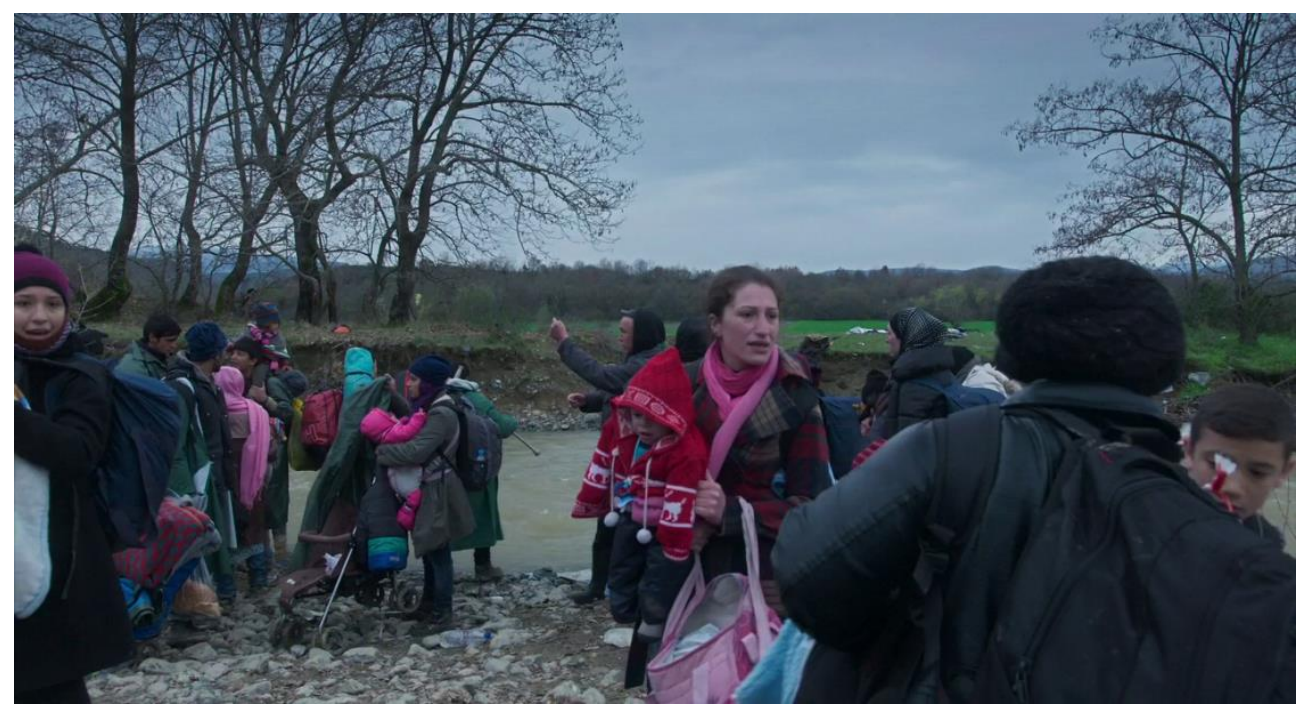

Figura 8 - Mães e pais com seus bebês tentando atravessar o córrego violento de um rio 


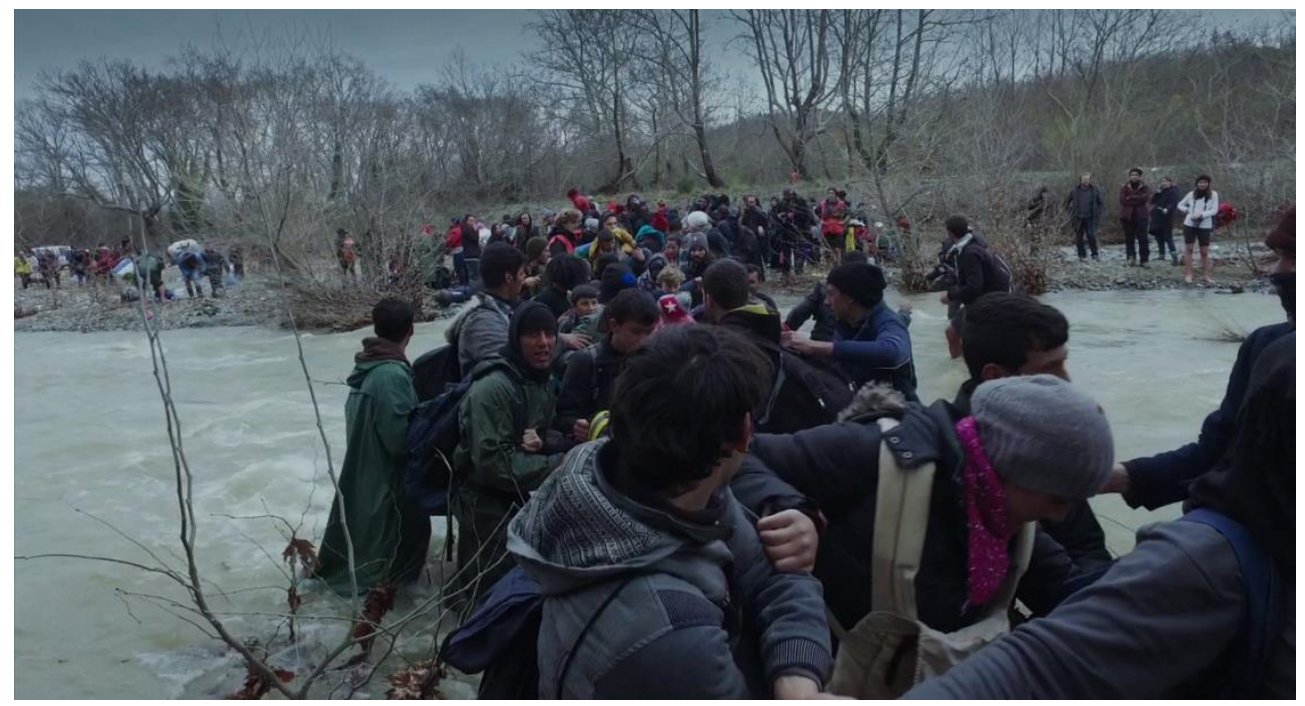

Figura 9 - O cordão humano feito pelos refugiados para atravessar as águas violentas de um rio

E quando eles parecem chegar hoje a algum lugar minimamente "firme" (ou quando chegaram ontem, ou quando chegarão amanhã), encontram sempre o mesmo estado de inimizade, hostilidade, desamparo e mesquinhez por parte das "autoridades", destes burocratas desumanos. Os homens da autoridade exercem sempre essa atmosfera que oprime (FIG. 10), como se em todos os campos de refugiados escutássemos as mesmas vozes iradas das "autoridades", os mesmos ruídos angustiosos dos refugiados, como se em cada momento todos os passos, todos os desejos deles pudessem ser impedidos no ressoar de uma sirene ou na fúria repentina de um burocrata. Talvez esteja nesta inermidade de seus desejos o que torna tudo sempre tão mórbido para eles: é preciso tanto para atravessar uma fronteira e tão pouco para que toda esta travessia seja ceifada, rompida, desmoronada.

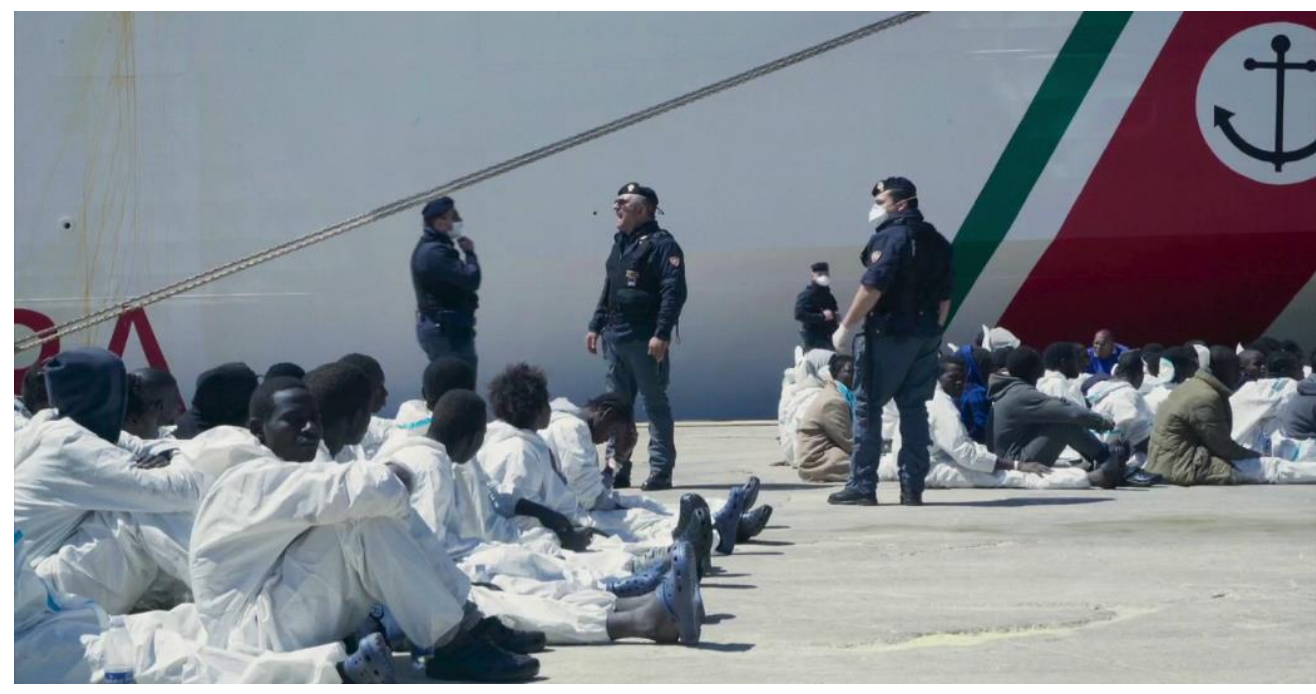

Figura 10 - Uma das tantas formas possíveis da hostilidade exercida pelas “autoridades" contra os refugiados 
E dos campos de refugiados, de seus alambrados e arames farpados (estas coisas insistentemente primitivas) uma semelhança cruel, de fato, acaba por suceder na "crise dos refugiados" e que Human Flow dá a ver com enorme nitidez: o retorno doloroso, sem dúvida, destes espaços concentracionários nas fronteiras europeias, onde num passado nem tão longínquo assim serviram como espaços de morte vinculados ao nazismo e seus aliados. Desde que existem alambrados e cercas de arames farpados, e cuja história política impecavelmente investigara Olivier Razac (2015), os campos, bem sabemos, espaçaram-se por todos os lados, começando pelos "campos de concentração" organizados pelos colonizadores britânicos na África do Sul na ocasião da segunda guerra dos Bóeres (18991902), ou pelo exército alemão do Segundo Reich na ocasião do genocídio dos Herero na Namíbia (1904).

$\mathrm{O}$ momento (FIG. 11), por exemplo, em que um jovem que pergunta à câmera de $\mathrm{Ai}$ Weiwei se as fronteiras em Idomeni serão abertas é um testemunho da violência simbólica e política dos campos de refugiados. Um enquadramento divisório testemunhamos aqui: nos quadriláteros do alambrado onde o rosto do jovem é enquadrado, a distância nada justa do olhar da câmera acaba por legitimar a exceção política - mas também territorial - da vida dos refugiados. E triste aporia destas vidas: fugir do genocídio perpetrado por seu próprio povo para tentar atravessar um território, uma fronteira onde muito possivelmente suas identidades, seus corpos como sujeitos políticos serão rechaçados pelas autoridades do novo país - de uma maneira, ao mesmo tempo semelhante e perversa, que o seu próprio país exercera, por causa da barbárie civil, com suas dignidades de seres humanos.

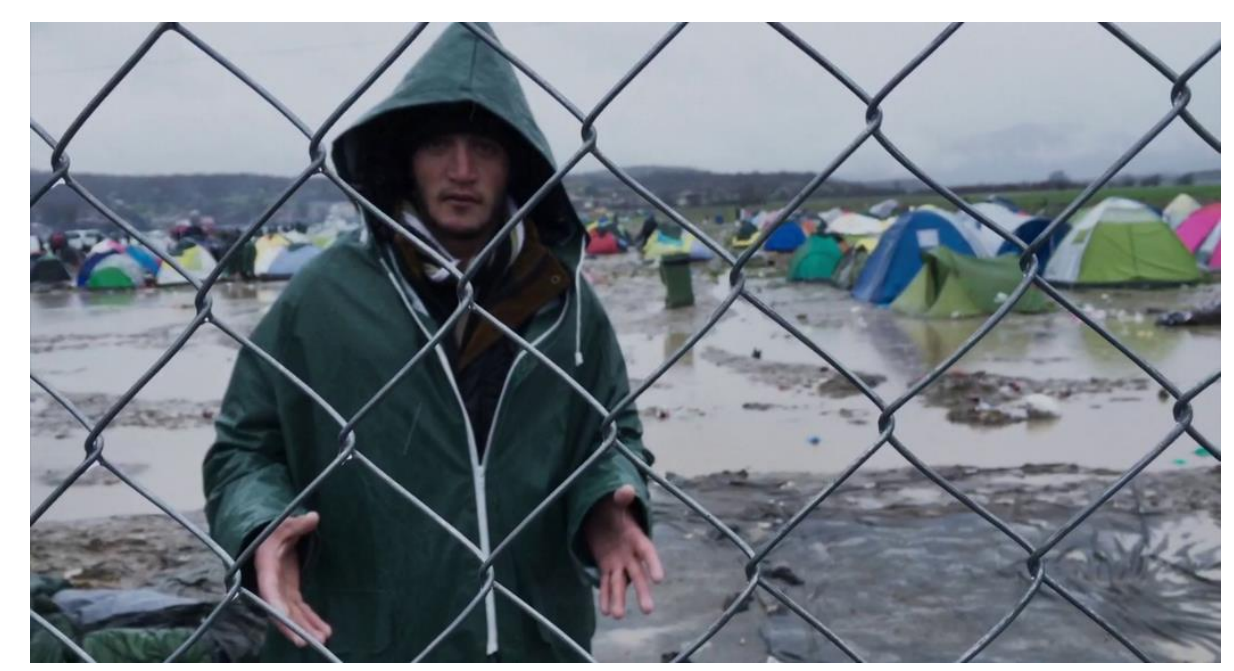

Figura 11 - Um plano que demonstra a violência simbólica e política dos campos de refugiados 
Por fim em Human Flow existem as crianças (FIG. 12). Vemo-las por todas as partes. Vemo-las tão pequenas, fazendo fila na lama, vestidas com esses tecidos impermeáveis exageradamente grandes para elas e que lhes conferem, mais do que aos adultos, esse toque espectral e sem dúvida tão vivaz, tão tenaz - elas que quase sempre nascem em farrapos e morrem em farrapos. Sabemos que estão entre as mais sofridas, as mais vulneráveis, as mais sobreviventes entre tantas outras crianças já mortas no mar ou na guerra. Mas as vemos sorrir, cantar, brincar somente com um punhado de nada, inventoras de um porvir surgido da maior pobreza. Deste gesto - desta resistência interminável, inexplicável - de serem capazes de oferecer um sorriso é porque nelas vivem ainda alguma coisa do atavismo, da genealogia, da história de seus ancestrais que não podem simplesmente ser renegadas: sejam já as religiões, as culturas, o desejo de viver, estas coisas seculares e sagradas que "iluminam essas imagens no fundo do silêncio":

os gestos dos refugiados tanto como as expressões de seus rostos. Os gestos são "seculares" porque são muito simples e antigos, e respondem a situações de urgência vital; são "sagrados" porque procedem de uma grande profundidade ética e cultural, onde as religiões, em muitos casos, ocupam um lugar central. Também os sorrisos são "seculares e sagrados". Vemo-los sucessivamente fatigadas e confiadas, tristes e generosas, ternas e valentes, pudicas e graciosas, dignas e inocentes, sociáveis e herméticas... Iluminam essas imagens no fundo do silêncio (DIDI-HUBERMAN, 2018, p. 68-69).

Sem dúvida estes olhares são sorridentes, como se eles tivessem percebido mais claramente do que qualquer outra coisa o próprio mistério e tivesse retrotraído, graças a sua compreensão, o sofrimento à uma dimensão tolerável.

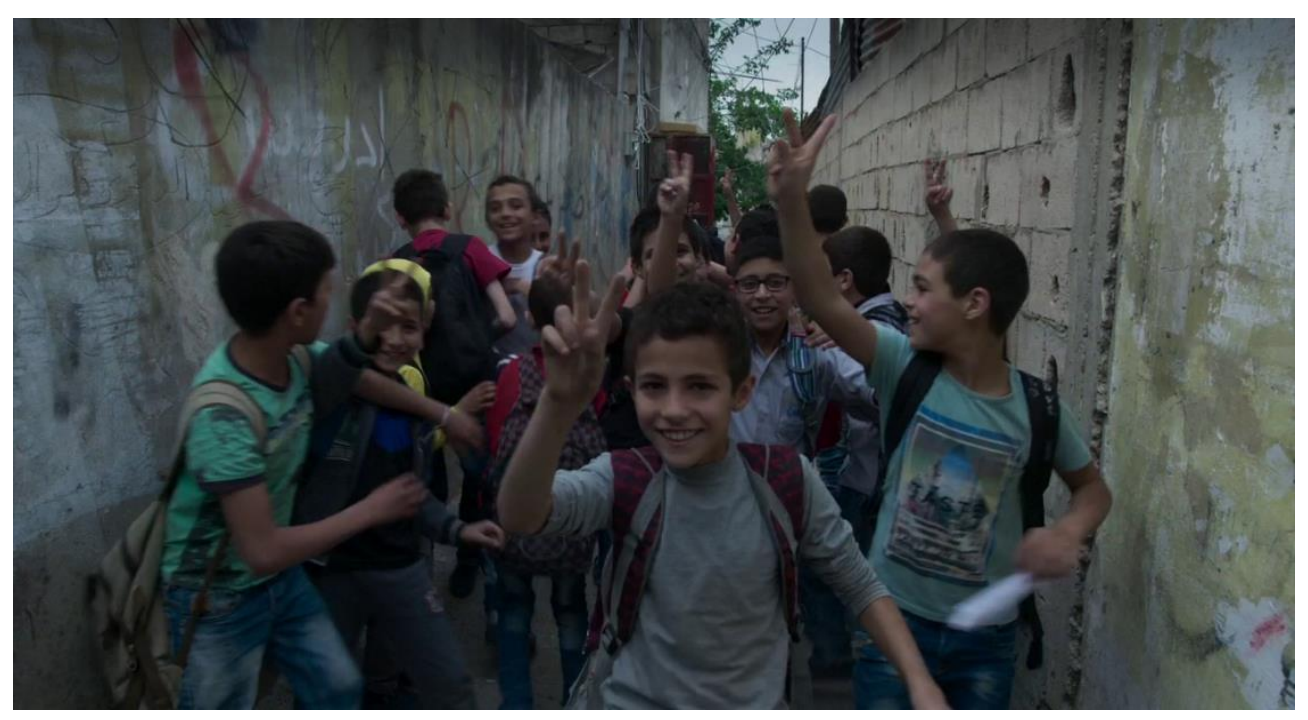

Figura 12 - As crianças refugiadas que são capazes de sorrir apesar de tudo 


\section{CONSIDERAÇÕES FINAIS}

\section{Homo sapiens, Homo migrans}

Em um pequeno e belo texto redigido muito recentemente em conjunto ${ }^{5}$ por Gilles Clément (jardineiro), Emanuele Coccia (filósofo), Antoine Kremer (geneticista), Jacques Tassin (agrônomo) e Sébastian Thiéry (politólogo), sua leitura nos demonstra que de fato as "migrações são uma condição da existência" e que os "povos obrigados a migrar, aspirando a condições toleráveis de vida, partem não em direção a espaços familiares equivalentes, mas para o estranho e o desconhecido de mundos possivelmente melhores” (CLÉMENT et al_, 2018, s/n).

A antropologia nos provou que somente foi possível que nos tornássemos Homo sapiens porque antes fomos, justamente, Homo migrans (migrante). É então quando seria preciso recordar um pouco melhor de onde todos nós viemos. Autobatizamo-nos Homo sapiens, mas é necessário refletir todavia de onde provém essa evolução decisiva que teria feito de nossos ancestrais tanto "sábios" como "inteligentes" (estes dois sentidos se reúnem no mesmo adjetivo sapiens). Mais precisamente como escreveu há alguns anos Hervé Le Bras, desde os tempos mais remotos os Homo sapiens foram seres migratórios e a sua sobrevivência, sem dúvida, deveu-se a essa condição singular que os nossos ancestrais sempre possuíram para atravessar as geografias (ao contrário, por exemplo, dos Neandertais ou dos Denisovanos que por não terem a migração como uma das condições de existência acabaram extintos), porque, escreve Le Bras, das "185 espécies de primatas subsistentes, somente o homem tem um comportamento migratório" (LE BRAS, 2012, p. 31).

É por termos sido desde o nosso surgimento mais primitivo seres migratórios que conseguimos simplesmente resistir às mudanças climáticas, às mudanças territoriais ao longo dos tempos. E talvez seja isto que Human Flow dá a ver: os refugiados que assumem uma vez mais (pois a história nunca deixará de desafiá-los) as carnaduras falsamente orgulhosas do visível. São elas que demonstram que a compaixão é justificada mas inútil, as que desmascaram, com seu pavor discreto, o luxo da aparência daqueles que ignoram esta crise não somente europeia, senão do mundo. Quem vê os refugiados em sua insistência desesperada para atravessar, custe o que custar, as fronteiras, quem os percebe em seu

\footnotetext{
${ }^{5}$ Agradecemos ao Vinícius Nicastro Honesko tanto por nos ter apresentado o texto quanto pela tradução do mesmo.
} 
sofrimento sem dimensão apesar dos esforços que tratam de ocultar a miséria de seu destino, pode só assim considerar o tamanho do preço que eles pagam por habitar este mundo.

Vendo Human Flow, vendo então suas imagens que nos dilaceram, conseguimos perceber - e consequentemente responder algumas questões cruciais de nosso texto - as razões pelas quais os refugiados são sentidos como uma ameaça, como seres hostis: é justamente pela proximidade de seus rostos, de seus desejos com os rostos e os desejos dos homens da civilização, dos "autóctones". Talvez seja por isso que eles sejam sistematicamente compreendidos como seres abjetos, como coisas, sem dúvida, portadoras de uma enfermidade contagiosa, mortal - esta compreensão reside justamente na pedra angular, para o mundo ocidental, na invenção de uma diferença inexistente entre os que tem uma pátria e os que não a tem. Quando uma sociedade começa a confundir seu vizinho com o inimigo, ou melhor o estrangeiro com o perigo, quando inventa instituições para pôr em ato esta confusão paranoica, então podemos dizer, com toda lógica histórica - e não segundo um simples ponto de vista ético -, que está perdendo sua cultura, sua própria capacidade de civilização.

Para terminar, Félix Guattari em um célebre diálogo com Gilles Deleuze (1992, p. 30) comenta que a ideia mesma de um fluxo (flow) está intimamente ligada à ideia de fuga, à ideia de fazer fugir (como a água de um cano que se arrebenta) o nosso desejo enquanto resposta ao fascismo do poder ${ }^{6}$. Não seria isto que justamente os refugiados, como incalculáveis fluxos humanos (human flows), realizam? Eles estão sempre fugindo, escapando, é dizer, atravessando os muros e alambrados que se opõem aos seus desejos de avançar para a vida apesar de tudo. E simplesmente não existe maneira de conter este fluxo (flow), este desejo pese todas as políticas desumanas, pese todos os tratados internacionais perversos. Porque por trás de todo ser humano reside uma força, uma potência que é capaz de fazer-lhe atravessar, custe o que custar, o mundo.

\section{REFERÊNCIAS}

AGAMBEN, Giorgio. Homo sacer: o poder soberano e a vida nua. Belo Horizonte: Editora UFMG, 2002.

AGAMBEN, Giorgio. Medios sin fin. Valencia: Pre-textos, 2001.

ARENDT, Hannah. Nós, os refugiados. Covilhã: LusoSofia press, 2013.

\footnotetext{
${ }^{6}$ Como fascismo do poder entendemos a sistemática irrupção daquilo que hoje se reconhece como "extrema direita" ou "direita radical". Sobre isso recentemente Riccardo Marchi e Guido Bruno (2016) puderam explicar com notável mérito o que reside nesta relação perversa entre os governos europeus de extrema direita e os refugiados.
} 
ARENDT, Hannah. Origens do totalitarismo. São Paulo: Companhia das Letras, 1989.

ARENDT, Hannah. The Jewish Writings. Nova York: Schocken Books, 2007.

BBC. Ai Weiwei's studio destroyed. 2018. Disponível em: https://www.bbc.com/news/av/worldasia-china-45073423/ai-weiwei-s-studio-destroyed Acesso em: 19/09/2018.

CLÉMENT, Gilles et al. Migrar, uma condição de existência do vivente. 2018. Disponível em: https://flanagens.blogspot.com/2018/09/migrar-uma-condicao-de-existencia-do.html Acesso em: $25 / 09 / 2018$

DELEUZE, Gilles. Conversações. São Paulo: Editora 34, 1992.

DERRIDA, Jacques. Da hospitalidade. São Paulo: Escuta, 2003.

DERRIDA, Jacques. Espectros de Marx: o estado da dívida, o trabalho do luto e a nova internacional. Rio de Janeiro: Relume-Dumará, 1994.

DERRIDA, Jacques. Manifeste pour l'hospitalité. Paris: Éditions Paroles d'Aube, 1999.

DIDI-HUBERMAN, Georges. Pasar, cueste lo que cueste. Cantabria: Shangrila Textos Aparte, 2018.

FIDDIAN-QASMIYEH, E. IN: LOESCHER, G.; LONG, K.; SIGONA, N. (Orgs.). The Oxford

handbook of refugee and forced migration studies. Oxford: Oxford University Press, 2014.

HEIDEGGER, Martin. A Origem da Obra de Arte. Lisboa: Edições 70, 2005.

LE BRAS, Hervé. Le sol et le sang. Rhétoriques de l'invasion. La Tour-d'Aigues: Editions de l'Aube, 2012.

MARCHI, Riccardo; BRUNO, Guido. A extrema-direita europeia perante a crise dos refugiados. IN: Relações Internacionais, ${ }^{\circ}$ 50, junho, pp. 39-56, 2016.

RAZAC, Olivier. Historia política del alambre de espino. Santa Cruz de Tenerife: Melusina, 2015.

RICHMOND, A. H. Reactive migration: sociological perspectives on refugee movements. IN: Journal of Refugee Studies, v. 6, n. 1, p. 7-24, 1993.

SIMMEL, Georg. O estrangeiro. In: RBSE, v. 4, nº 12, dezembro, 2005. 
Ricardo Lessa Filho Doutor pelo Programa de Pós-Graduação em Comunicação da Universidade Federal de Pernambuco. Mestre pelo mesmo programa/instituição. Membro do grupo de pesquisa Representación Contemporánea de los Perpetradores (REPERCRI) vinculado à Universidad de Valencia (Espanha).

Frederico Vieira Doutor pelo Programa Pós-Graduação em Comunicação da Universidade Federal de Minas Gerais (UFMG). Professor do Curso de Graduação em Relações Públicas (PUC-MG). Integra o Grupo de Pesquisa Lévinas e Alteridades, ligado à Faculdade Jesuíta de Filosofia e Teologia em Belo Horizonte; o Grupo Mobiliza, da UFMG, que se concentra nos estudos de Comunicação para Mobilização Social

e Opinião Pública.

\section{@ (요요}

Esta obra está licenciada com uma Licença

Creative Commons Atribuição-NãoComercial-CompartilhaIgual 4.0 Internacional 